\title{
Analyzing the Construct Validity of Organizational Citizenship Behavior Scale Using Confirmatory Factor Analysis with Indonesian Samples
}

\author{
Ulfiani Rahman ${ }^{1}$, Wan Shahrazad Wan Sulaiman ${ }^{1}$, Rohany Nasir ${ }^{1} \&$ Fatimah Omar $^{1}$ \\ ${ }^{1}$ School of Psychology and Human Development, Faculty of Social Sciences and Humanities, Universiti \\ Kebangsaan Malaysia, UKM Bangi, Selangor, Malaysia \\ Correspondence: Wan Shahrazad Wan Sulaiman, School of Psychology and Human Development, Faculty of \\ Social Sciences and Humanities, Universiti Kebangsaan Malaysia, 43600 UKM Bangi, Selangor, Malaysia. Tel: \\ 60-3-8921-4190. E-mail: shara@ukm.my
}

Received: May 13, 2013 Accepted: July 14, 2013 Online Published: September 29, 2013

doi:10.5539/ass.v9n13p85 URL: http://dx.doi.org/10.5539/ass.v9n13p85

\begin{abstract}
The success of an organization is influenced by employees who not only perform their job, but also contribute their time and energy to provide assistance beside the formal obligations to the organization. This behavior is referred to as organizational citizenship behavior. This study was conducted to analyze the validity of the Organizational Citizenship Behavior Scale. Therefore, there were two main objectives in this study, namely to examine the construct validity of the Organizational Citizenship Behavior Scale using confirmatory factor analysis (CFA) and to assess the reliability of the scale. Organizational citizenship behavior was measured using three dimensions and they were helping behavior, civic virtue and sportsmanship. The study was conducted on 11 religious schools located in North, East, South, Middle and West of South Sulawesi, Indonesia. The schools consisted of 339 teachers. However, after examination of normality data, only 208 respondents were used as samples. The results of the study showed that the hypothesized model did not have a good fit to the data with Chi Square $=190.168, p<0.0001, \mathrm{CFI}=0.89, \mathrm{GFI}=0.92, \mathrm{TLI}=0.87, \mathrm{RMSEA}=0.078$. Thus, this model has to be revised. The results of the revised model showed a better fit with Chi Square $=118.335, p<0.0001, C F I=0.93$, GFI $=0.92$, TLI $=0.90$, RMSEA $=0.07$. The findings were discussed based on the suitability of the Organizational Citizenship Behavior Scale as a valid measure within Indonesian context.
\end{abstract}

Keywords: organizational citizenship behavior (OCB), confirmatory factor analysis (CFA), validity, reliability

\section{Introduction}

As the world enters into the era of globalization and technology, educational institutions must also change to keep pace with the current development. As such, it needs teachers who are committed and who are willing to go above and beyond the call of duty in order to create successful organizations. Teachers should be willing to not only perform the formal obligations given to them, but must also be willing to contribute their time and energy in the tasks besides their formal responsibilities. These include helping coworkers at the workplace, attending meetings voluntarily and responding to correspondence. This behavior is called organizational citizenship behavior.

Organizational citizenship behavior for teachers can be defined as the behavior that is performed voluntarily by teachers in schools. They do not expect any reward, and the behaviors are not related to the formal reward system and it can enhance the functioning of the organization. Organ (1988) defined organizational citizenship behaviors as "individual behavior that is discretionary, not directly or explicitly recognized by the formal reward system, and that in the aggregate promotes the effective functioning of the organization" (p. 4). Organizational citizenship behavior among teachers is important as it relates to other factors such as job satisfaction, burnout, organizational commitment and performance. Therefore, the measurement of organizational citizenship behavior needs to be accurate to indicate whether teachers have organizational citizenship behavior in their work.

Past studies found that the various scales to measure organizational citizenship behavior have good reliability. However, a review of the literature in this area reveals a lack of consensus about the dimensionality of this construct. Podsakoff, MacKenzie, Paine and Bachrach (2000) identified seven common themes or dimensions 
namely: (1) helping behavior, (2) sportsmanship, (3) organizational loyalty, (4) organizational compliance, (5) individual initiative, (6) civic virtue, and (7) self development, though five dimensions of OCB were more commonly tested. For example, Podsakoff, MacKenzie, Moorman and Fetter (1990) used a 24-item scale developed through a series of stages in which they administered the scale in a sample of 988 employees working for a diversified petrochemical company throughout the United States, Canada and Europe. They obtained an average internal consistency reliability of 0.81 with altruism $=0.85$, courtesy $=0.85$, sportsmanship $=0.85$, conscientiousness $=0.82$, and civic virtue $=0.70$. Validity was assessed using test of discriminant validity and the results found that all of the constructs were empirically distinct, although altruism shared about two thirds of its variance with conscientiousness and courtesy. Lam, Hui and Law (1999) found that the five-factor structure of organizational citizenship behaviors (OCBs)-altruism, conscientiousness, civic virtue, courtesy, and sportsmanship-was replicated in Japan, Australia, and Hong Kong.

Podsakoff and MacKenzie (1994) then developed the supervisor ratings of employee OCB using a 14-item scale measuring different types of organizational citizenship including helping, civic virtue, and sportsmanship. Supervisors were asked to rate the OCB of their subordinates using a seven-point scale ranging from (1) strongly disagree to (7) strongly agree. Based on the recommendations of LePine, Erez and Johnson (2002), these items were aggregated to create an overall measure of OCB. Cronbach's alpha for this scale was 0.87 .

Podsakoff, Ahearne, and McKenzie (1997) combine the dimensions of altruism, diligence, and civilization in one dimension called helping behavior. Previous empirical research by MacKenzie, Podsakoff, and Fetter (1991, 1993) and MacKenzie, Podsakoff, and Ahearne (1998) confirmed the adequacy of the OCB scale's psychometric properties. Each of three constructs (sportsmanship, helping behavior \& civic virtue) included items describing specific behaviors, and sales managers were required to indicate their agreement for each item using a seven-point Likert format. Data analysis via measurement model was conducted using the two-step approach proposed by Anderson and Gerbing (1988). Results showed that the first-order factors corresponded to a seven-item helping behavior, a three-item civic virtue factor, and a four-item sportsmanship factor. Results showed that all item-loadings for each factor were significant at $\mathrm{p}<0.01$. Results also found that the overall fit of the measurement model was acceptable $\left(\chi^{2}=451.32, \mathrm{p}<0.01\right.$; GFI $=0.91$; AGFI $=0.90$; RMR $=0.07$; TLI $=$ 0.94 ; $\mathrm{CFI}=0.95$ ). In addition, Cronbach's construct reliability and composite reliability provided evidence of internal consistency ranging from 0.80 to 0.88 .

The three dimensions of OCB are supported in studies by Netemeyer, Boles, McKee and McMurrian (1997), Organ and Konovsky (1989) and Williams and Anderson (1991) who state that: (1) helping behavior refers to the attitude that describes employees' behavior who help fellow employees such as helping a colleague solve a difficult task or helping new workers adapt to the new environment; (2) civic virtue, refers to actions that are demonstrated by the constructive action and attitude in performing the tasks in the organization, such as attendance at meetings voluntarily and response to any correspondence quickly; and (3) sportsmanship refers to the desire of employees to be tolerant to unsupportive attitudes that may occur in the workplace, for example, not complaining about minor problems and not finding fault with other workers. The empirical evidence by Netemeyer et al. (1997), Organ and Konovsky (1989) and Williams and Anderson (1991) supported the three dimensions of OCB. Therefore, this study attempts to confirm the construct validity of these three dimensions of OCB within Indonesian context.

Empirical studies in Indonesia examined the relationship between organizational citizenship behavior with other work constructs such as leadership and organizational commitment and results of significant correlations among these variables provided evidence of criterion validity for the OCB scale. For instance, a study by Lamidi (2008) among 42 lecturers in a university in Surakarta, Indonesia found a significant relationship between transformational leadership, organizational commitment and OCB. Veronika Agustini Srimulyani (2012) examined the direct and indirect effects of transformational leadership on OCB mediated by work life quality and organizational commitment. Participants consisted of 165 teachers of 5 senior high schools in Madiun, Indonesia. Results of path analysis showed that transformational leadership, work life quality and organizational commitment have a direct and significant effect on OCB. In addition, a study conducted on 190 high school teachers in Surabaya, Indonesia by Kaihatu and Rini (2007) found reliability coefficients of OCB scale of 0.60 and above.

\section{Method}

\subsection{Respondents}

The participants in this study were 339 teachers who were employed in the senior high school or Madrasah Aliyah Negeri of South Sulawesi selected using stratified random sampling. After analysis of normality, only 208 respondents were used as samples. 


\subsection{Research Instruments}

The Organizational Citizenship Behavior Scale used in this research was developed by Netemeyer et al. (1997), Organ and Konovsky (1989) and Williams and Anderson (1991). The scale comprised of 13 items and measured three dimensions which were: helping behavior with 5 items, civic virtue with 4 items, and sportsmanship with 4 items. The responses used five point Likert scale with $5=$ Strongly Agree, $4=$ Agree, $3=$ Neutral, $2=$ Disagree, and $1=$ Strongly Disagree.

\subsection{Data Analysis}

Confirmatory factor analysis (CFA) using the AMOS data-fitting program was applied to confirm the construct validity of items and constructs. The estimation of parameters was based on the maximum likelihood estimation (MLE) method. The use of MLE assumes that the following conditions to be met especially when the data are Likert-type scale: (i) the sample is very large, (ii) the distribution of the observed variables is multivariate normal, (iii) the hypothesized model is valid (West, Finch \& Curran, 1995), and (iv) the scale is continuous. Analysis was done by CFA or measurement models to test how well measured variables represent a smaller number of constructs. It was also used to provide a confirmatory test of the measurement theory. The measurement theory specified a series of relationships that suggested how measured variables represent a latent construct that was not measured directly.

The goodness of fit of the models was evaluated using six indices, which reflected the overall model fit: (1) the chi-square statistic; (2) the minimum value of the discrepancy between the observed data and the hypothesized model divided by degrees of freedom (CMIN/DF). Arbuckle and Wothke (1995) pointed out that the CMIN/DF with a value of less than 5.0 is considered acceptable; (3) the goodness-of-fit index (GFI); (4) the comparative fit index (CFI); (5) the Tucker-Lewis index which compared the estimated model with the null model. The GFI, CFI and TLI usually vary along a 0 to 1 continuum in which values greater than 0.90 and 0.95 are typically taken to reflect acceptable and excellent fit to the data (Schumacker \& Lomax, 1996); and (6) the root mean-square error of approximation (RMSEA) was also presented. Browne and Cudeck (1993) suggest that RMSEA less than 0.05 is indicative of a "close fit" and that values up to 0.08 represent reasonable errors of approximation.

\section{Results}

The respondents' demographic profile is presented in Table 1. A total of 138 respondents $(41 \%)$ were male teachers while another 201 respondents $(59 \%)$ were female teachers. They ranged in age with 35 respondents $(10 \%)$ aged between 20 to 30 years old, 140 respondents (41\%) between 31 to 40 years old, 142 respondents (42\%) between 41 to 50 years old, and 22 respondents $(7 \%)$ between 51 to 60 years old. The majority of the respondents $(82 \%)$ were married, while 56 respondents $(17 \%)$ were still single and 4 respondents $(1 \%)$ were divorced. One respondent $(0.3 \%)$ had only a high school education, 295 respondents $(87 \%)$ hold a Bachelor's degree, 42 respondents $(12.4 \%)$ had a Masters' degree, and one respondent $(0.3 \%)$ hold a $\mathrm{PhD}$ degree. Respondents also varied in their length of service, with 169 respondents $(50 \%)$ have worked less than 10 years, 143 respondents (42\%) have worked between 11 to 20 years, 25 respondents (7\%) have worked between 21 to 30 years, and two respondents (1\%) have worked between 31 to 40 years.

Table 1. Respondents' demographic profile

\begin{tabular}{llll}
\hline Demography & & Frequency & Percentage (\%) \\
\hline Gender & Male & 138 & 41.0 \\
Age & Female & 201 & 59.0 \\
& $20-30$ yrs & 35 & 10.0 \\
& $31-40$ yrs & 140 & 41.0 \\
Marital status & $41-50$ yrs & 142 & 42.0 \\
& $51-60$ yrs & 22 & 7.0 \\
\multirow{3}{*}{ Education } & Single & 56 & 17.0 \\
& Married & 279 & 82.0 \\
& Divorced & 4 & 1.0 \\
\multirow{4}{*}{ Length of service } & High school & 1 & 0.3 \\
& Bachelor & 295 & 87.0 \\
& Masters & 42 & 12.4 \\
& PhD & 1 & 0.3 \\
& Below 10 yrs & 169 & 50.0 \\
& $11-20$ yrs & 143 & 42.0 \\
& $21-30$ yrs & 25 & 7.0 \\
& $31-40$ yrs & 2 & 1.0 \\
\hline
\end{tabular}


The first objective of this study was to examine the construct validity of the Organizational Citizenship Behavior scale. The model was tested using confirmatory factor analysis on three dimensions of organizational citizenship behavior. These latent variables were formed by three dimensions with helping behavior containing 5 items, civic virtue containing 4 items, and sportsmanship containing 4 items.

Figure 1 and Table 2 show the results of the hypothesized measurement model of organizational citizenship behavior. Results showed that the model did not have a good fit to the data with Chi Square $=190.168, \mathrm{p}<$ $0.0001, \mathrm{CMIN} / \mathrm{df}=3.07, \mathrm{GFI}=0.92, \mathrm{TLI}=0.87, \mathrm{CFI}=0.89$ and $\mathrm{RMSEA}=0.78$. The data revealed that the fit statistics for the measurement model did not fulfill the requirement of the conventional standards for CFI, GFI and TLI (Byrne, 2001). Therefore, the model needs to be revised.

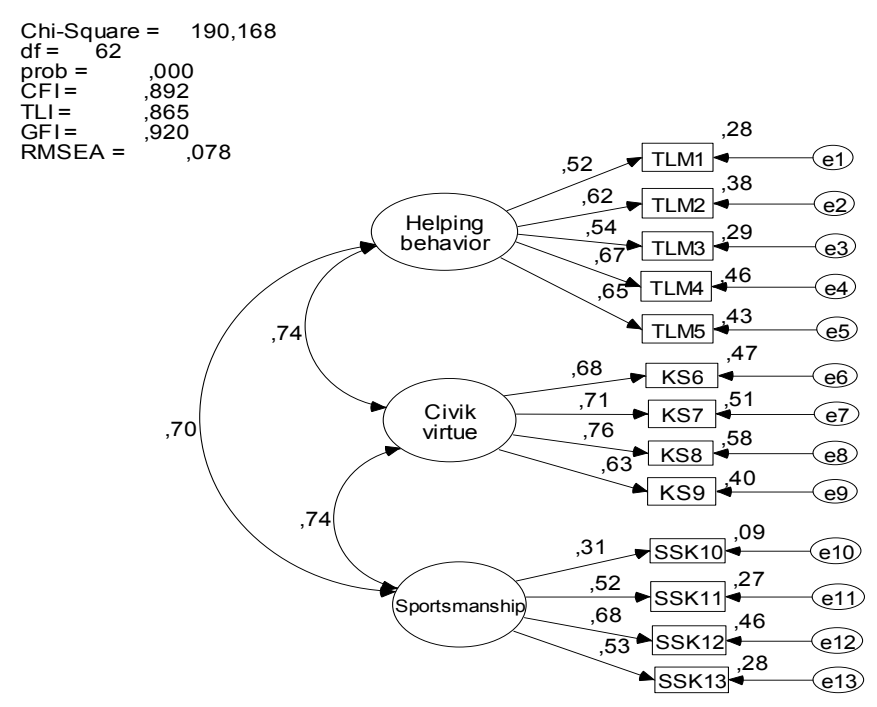

Figure 1. The results of the hypothesized measurement model of organizational citizenship behavior

The revision of the model was done using modification indices (MI) (Kline, 2005; Byrne, 2001). Several error variances were correlated as suggested by modification indices such as: e1 = "I give my time to help employees with work- related problems" and e2 = "I support employees who have problems at work"; e1 = "I give my time to help employees with work- related problems" and e3 = "I take time out of my day to help train new employees"; e5 = "I share my knowledge and expertise with other employees" and e12 = "I focus on the positive aspects of my work" which indicated that these items were strongly related with each other. Results of the revised measurement model as shown in Figure 2 and Table 1 indicated a better fit model, with Chi-Square $=$ $115.400, \mathrm{p}<0.0001, \mathrm{CMIN} / \mathrm{df}=2.01, \mathrm{GFI}=0.92, \mathrm{TLI}=0.90, \mathrm{CFI}=0.93$ and $\mathrm{RMSEA}=0.07$. 


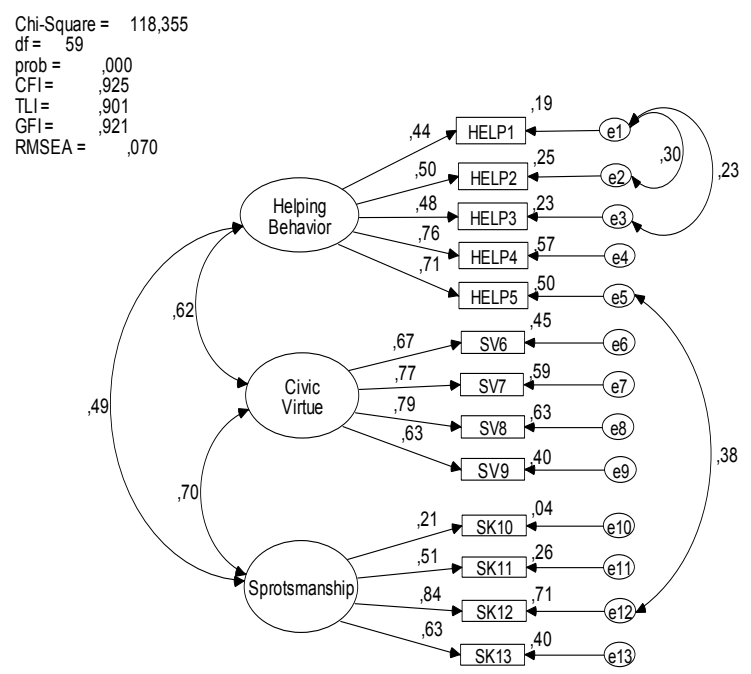

Figure 2. The results of the revised measurement model of organizational citizenship behavior

Table 2. Results of goodness-of-fit indices of hypothesized and revised measurement model of organizational citizenship behavior

\begin{tabular}{llll}
\hline Indices & Recommended & Hypothesized Model & Revised Model \\
\hline Chi-square & $>0.05$ & $656.986^{*}$ & $118.355^{*}$ \\
CMIN/df & $<5.0$ & 3.067 & 2.006 \\
GFI & $>0.90$ & 0.83 & 0.92 \\
TLI & $>0.90$ & 0.82 & 0.90 \\
CFI & $>0.90$ & 0.84 & 0.93 \\
RMSEA & $<0.08$ & 0.08 & 0.07 \\
\hline
\end{tabular}

The second objective was to assess the reliability of the organizational citizenship behavior scale. The hypothesized and revised model tested consisted of 13 items. No item was eliminated in the revision process. Consequently the results of internal consistency showed a moderate to high Cronbach alpha of 0.82 for the total scale and $\alpha=0.73$ for helping behavior, $\alpha=0.54$ for civic virtue, and $\alpha=0.81$ for sportsmanship. The results of reliability showed that the scale has satisfactory internal consistency for the overall scale and its dimensions.

\section{Discussion}

The study showed that the revised model indicated a better fit with three dimensions of organizational citizenship behavior which were helping behavior, civic virtue and sportsmanship. This showed that teachers can work with each other in a voluntary behavior outside their formal responsibility in the school. This is because teachers in religious schools perform their duties based on their religious beliefs. The teachers have the belief that the work must start with good intentions, and thus teachers perform their job based on the desire to reach success together. In addition, sportsmanship behavior which is showing the desire of employees to be tolerant with coworkers in performing the job was also shown by these respondents. Examples of this behavior include not reporting unimportant problems and not finding fault with coworkers. This behavior is also stressed as a good virtue in Islam. Respondents in this study also possessed helping behavior which is described as wanting to help coworkers such as helping coworkers finish difficult tasks, give help to new workers to adapt to the workplace. The respondents also showed civic virtue which is demonstrated by the constructive action and attitude in performing the tasks in the organization. Examples of this behavior are coming to meetings voluntarily, giving response to organizational matters that need prompt solving.

Based on the results, the OCB scale showed a better fit by including a covariance between error measurements among items in helping behavior and a covariance of error measurement between items in helping behavior and 
sportsmanship based on the modification indices. Higher loadings on items measuring civic virtue indicates that this behavior is deemed important that leads to constructive action in organizational activities. This is followed by helping behavior which describes the behavior of employees who like to help co-workers. Teachers also exhibit sportsmanship behavior which means that they are willing to tolerate minor setbacks that may occur in the workplace. Therefore, these findings indicate that teachers are conscious of their responsibility in improving organizational effectiveness.

There are several reasons why citizenship behavior should be established. The emphasis on organizational citizenship behavior can reduce lazy workers from arising due to ambiguity in the workplace. Having organizational citizenship behavior also reduces the need for rare specialized resources when employees emphasize extra role behavior. In addition, educational institutions can create an environment that will lead to organizational citizenship behavior and this in turn reduces barriers among employees.

\section{Conclusion}

This study tested three dimensions of OCB, helping behavior, civic virtue and sportsmanship which are similar to those that have been empirically investigated in the Western OCB literature. Based on the results of validity, the OCB scale showed a good fit with the data. Organizational citizenship behavior in this study was validly measured by aspects of civic virtue, helping behavior and sportsmanship. The results of reliability analysis were also satisfactory for three dimensions and all items. The implication of this finding is that it shows the importance of establishing organizational citizenship behavior at the workplace. By having organizational citizenship behavior, employees are willing to perform extra role behavior and this can reduce the need for rare specialized resources. Thus it can be concluded that the scale is suitable to be used in the local context. This demonstrated the scale has construct validity and reliability and the scale is suitable to measure OCB among Indonesian samples. This also suggests that these three dimensions have broad applicability across Indonesian culture.

\section{References}

Anderson, J. C., \& Gerbing, D. W. (1988). Structural equation modeling in practice: A review and recommended two-step approach. Psychological Bulletin, 103(3), 411-423. http://dx.doi.org/10.1037/0033-2909.103.3.411

Arbuckle, J. L., \& Wothke, W. (1995). AMOS 4.0 user's guide. Chicago: Small Waters Corporation.

Browne, M. W., \& Cudeck, R. (1993). Alternative ways of assessing model fit. In K. A. Bollen \& J. S. Long (Eds.), Testing structural equation models (pp. 136-162). Newbury Park, CA: Sage. ISBN 0803945078 9780803945074

Byrne, B. M. (2001). Structural equation modeling with AMOS: Basic concepts, applications and programming. Mahwah, NJ: Erlbaum. ISBN 08058410409780805841046

Kaihatu, T. S., \& Rini, W. A. (2007). Kepemimpinan transformasional dan pengaruhnya terhadap kepuasan atas kualitas kehidupan kerja, komitmen organisasi, dan perilaku ekstra peran: Studi pada Guru-Guru SMU di Kota Surabaya. Jurnal Manajemen dan Kewirausahaan, 98(1), 49-61.

Kline, R. B. (2005). Principles and practice of structural equation modeling (2nd ed.). New York: The Guilford Press. ISBN 15938507519781593850753

Lam, S. S. K., Hui, C., \& Law, K. S. (1999). Organizational citizenship behavior: Comparing perspectives of supervisors and subordinates across four international samples. Journal of Applied Psychology, 84(4), 594-601. http://dx.doi.org/10.1037/0021-9010.84.4.594

Lamidi. (2008). Pengaruh kepemimpinan transformasional terhadap organization citizenship behavior dengan variable intervening komitmen organisasional. Jurnal Ekonomi dan Kewirausahaan, 8(1), 25-37.

LePine, J. A., Erez, A., \& Johnson, D. E. (2002). The nature and dimensionality of organizational citizenship behavior: A critical review and meta-analysis. Journal of Applied Psychology, 87(1), 52-65. http://dx.doi.org/10.1037/0021-9010.87.1.52

MacKenzie, S. B., Podsakoff, P. M., \& Ahearne, M. (1998). Some possible antecedents and consequences of in-role and extra-role salesperson performance. Journal of Marketing, 62(3), 87-98. Retrieved from http://www.jstor.org/stable/1251745 http://dx.doi.org/10.2307/1251745

MacKenzie, S. B., Podsakoff, P. M., \& Fetter, R. (1991). Organizational citizenship behavior and objective productivity as determinants of managerial evaluations of salespersons' performance. Organizational Behavior and Human Decision Processes, 50, 123-150. http://dx.doi.org/10.1016/0749-5978(91)90037-T

MacKenzie, S. B., Podsakoff, P. M., \& Fetter, R. (1993). The impact of organizational citizenship behavior on evaluations of sales performance. Journal of Marketing, 57(1), 70-80. Retrieved from http://www.jstor.org/stable/1252058 http://dx.doi.org/10.2307/1252058 
Netemeyer, R. G., Boles, J. S., McKee, D. O., \& McMurrian, R. (1997). An investigation into the antecedents of organizational citizenship behaviors in a personal selling context. Journal of Marketing, 61(3), 85-98. Retrieved from http://www.jstor.org/stable/1251791 http://dx.doi.org/10.2307/1251791

Organ, D. W. (1988). Organizational citizenship behavior: The good soldier syndrome. Lexington, MA: Lexington Books. ISBN 06691178899780669117882

Organ, D. W., \& Konovsky, M. (1989). Cognitive versus affective determinants of organizational citizenship behavior. Journal of Applied Psychology, 74(1), 157-164. http://dx.doi.org/10.1037/0021-9010.74.1.157

Podsakoff, P. M., \& McKenzie, S. B. (1994). Organizational citizenship behavior and sales unit effectiveness. Journal of Marketing Research, 31(3), 351-363. Retrieved from http://www.jstor.org/stable/3152222 http://dx.doi.org/10.2307/3152222

Podsakoff, P. M., Ahearne, M., \& McKenzie, S. B. (1997). Organizational citizenship behavior and the quantitative and qualitative of work group performance. Journal of Applied Psychology, 82(2), 262-270. http://dx.doi.org/10.1037/0021-9010.82.2.262

Podsakoff, P. M., MacKenzie, S. B., Moorman, R. H., \& Fetter, R. (1990). Transformational leader behaviors and their effects on followers' trust in leader, satisfaction, and organizational citizenship behaviors. Leadership Quarterly, 1(2), 107-142. http://dx.doi.org/10.1016/1048-9843(90)90009-7

Podsakoff, P. M., MacKenzie, S. B., Paine, J. B., \& Bachrach, D. G. (2000). Organizational citizenship behaviors: A critical review of the theoretical and empirical literature and suggestions for future research. Journal of Management, 26(3), 513-563. http://dx.doi.org/10.1177/014920630002600307

Schumacker, R. E., \& Lomax, R. G. (1996). A beginner's guide to structural equation modeling. Mahwah, NJ: Lawrence Erlbaum Associates. ISBN 08058401849780805840186.

Srimulyani, V. A. (2012). Anteseden organizational citizenship behavior: Studi pada guru-guru SMA di Kota Madiun. Widya Warta, No. 1 Tahun XXXV. ISSN 0854-1981.

West, S. G., Finch, J. F., \& Curran, P. J. (1995). Structural equation models with non-normal variables: Problems and remedies. In R. H. Hoyle (Ed.), Structural equation modeling: Concepts, issues and applications. Thousand Oaks, CA: Sage Publications. ISBN 08039531869780803953185.

Williams, L. J., \& Anderson, S. E. (1991). Job satisfaction and organizational commitment as predictor of organizational citizenship and in-role behaviors. Journal of Management, 17(3), 601-617. http://dx.doi.org/10.1177/014920639101700305

\section{Copyrights}

Copyright for this article is retained by the author(s), with first publication rights granted to the journal.

This is an open-access article distributed under the terms and conditions of the Creative Commons Attribution license (http://creativecommons.org/licenses/by/3.0/). 